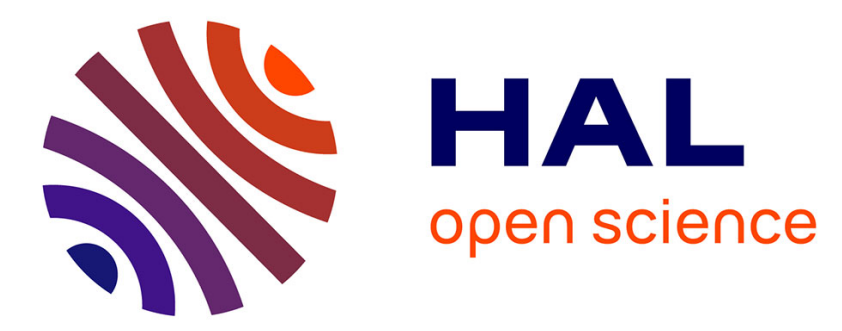

\title{
Mapping Rm2 gene conferring resistance to the green peach aphid (Myzus persicae Sulzer) in the peach cultivar "Rubira ${ }^{\circledR} "$
}

\author{
Patrick Lambert, Thierry Pascal
}

\section{- To cite this version:}

Patrick Lambert, Thierry Pascal. Mapping Rm2 gene conferring resistance to the green peach aphid (Myzus persicae Sulzer) in the peach cultivar "Rubira®". Tree Genetics and Genomes, 2011, 7 (5), pp.1057-1068. 10.1007/s11295-011-0394-2 . hal-02652429

HAL Id: hal-02652429

https: / hal.inrae.fr/hal-02652429

Submitted on 29 May 2020

HAL is a multi-disciplinary open access archive for the deposit and dissemination of scientific research documents, whether they are published or not. The documents may come from teaching and research institutions in France or abroad, or from public or private research centers.
L'archive ouverte pluridisciplinaire HAL, est destinée au dépôt et à la diffusion de documents scientifiques de niveau recherche, publiés ou non, émanant des établissements d'enseignement et de recherche français ou étrangers, des laboratoires publics ou privés.

\section{(ㄷ)(1) $\$$}

Distributed under a Creative Commons Attribution - NonCommerciall 4.0 International 
Version définitive du manuscrit publié dans / Final version of the manuscript published in : Tree Genetics \& Genomes, 2011, vol., no., pp , DOI 10.1007/s11295-011-0394-2

\title{
Mapping $R \boldsymbol{R} 2$ gene conferring resistance to the green peach aphid (Myzus persicae Sulzer) in the peach cultivar "Rubira ${ }^{\circledR}$ ",
}

\author{
P. Lambert and T. Pascal \\ ${ }^{1}$ INRA, Unité de Génétique et d'Amélioration des Fruits et Légumes, Domaine Saint Maurice, \\ BP 94, 84143 Montfavet Cedex, France
}

\author{
Corresponding author \\ Patrick Lambert \\ Unité de Génétique et d'Amélioration des Fruits et Légumes \\ INRA \\ Domaine Saint Maurice \\ BP 94 \\ 84143 Montfavet Cedex
}

Phone: 33 (0) 432722815

Fax: 33 (0) 432722702

E-mail: patrick.lambert@avignon.inra.fr

\begin{abstract}
The green peach aphid (GPA), Myzus persicae (Sulzer), is a widespread pest insect that significantly reduces yield in peach orchards [Prunus persica (L.) Batsch]. Chemical control of the GPA population in the orchards showed little efficiency because of the development of resistance to most classes of insecticides. Biological control partially gave convincing results. Breeding for resistant peach cultivars is therefore a serious option to take into account for the development of sustainable pest management. Among the few available resistance cultivars, the rootstock peach "Rubira" ${ }^{\circledR}$ " shows a strong induced antixenosis-type GPA resistance. This was demonstrated segregating as a single dominant gene. In order to investigate the genetic basis of resistance and develop molecular tools useful in breeding programs, a $\mathrm{F}_{2}$ population derived from "Rubira ${ }^{\circledR}$ " also segregating for leaf color was grown and scored for GPA resistance under contrasted environmental conditions. A SSR-based genetic linkage map composed of 120 SSR loci spanned over a distance of $497.8 \mathrm{cM}$ was then established. The GPA resistance mapped to a single locus at the bottom end of linkage group 1. We propose to name $R m 2$ the dominant allele of the underlying gene. Additionally, a reciprocal translocation was identified near the $G r$ gene controlling leaf color. The red-leaf parent "Rubira" ${ }^{\circledR}$ " was demonstrated responsible for the translocation. This study provides the basis for future molecular analysis for the use of $R m 2$ in peach breeding programs against GPA in peach orchards.
\end{abstract}




\section{Introduction}

Challenging breeding programs have been developed since several years at INRA-Avignon to select new peach cultivars [Prunus persica (L.) Batsch] introgressed with resistance factors against several important pests and diseases (Kervella et al. 1998; Foulongne et al. 2003b; Decroocq et al. 2005; Rubio et al. 2010), such as powdery mildew (Sphaerotheca pannosa var. persicae), peach leaf curl (Taphrina deformans), sharka disease and the green peach aphid (GPA) [Myzus persicae (Sulzer)]. GPA is a European native aphid with a worldwide distribution. This generalist insect pest infests hundreds of species from 40 plant families (Blackman and Eastop 2000) and is commonly found in peach and nectarine orchards throughout Southern Europe and North America. In spring and summer, GPA reproduces parthenogenetically on peach tree, a primary host, and sexually in autumn. Heavy infestation causes direct damage to the trees due to penetration of stylet by founders into flowers and to development of colonies which are responsible for leaf curling, heavy breakdown in shoot growth by sucking the phloem-sap and reduced fruit quality due to aphid punctures (Sauge et al. 1998a; Pascal et al. 2002). Besides direct injuries to leaves, shoots and fruits, GPA may act as a vector of the plum pox potyvirus (PPV), the causative agent of sharka disease in Prunoideae (Decroocq et al. 2005). This is one of the most serious diseases affecting Prunus species in the whole world. GPA has a well-documented history of resistance to most classes of insecticides due to their continuous use to control infestation (Devonshire et al. 1998; Mazzoni and Cravedi 2002; Foster et al. 2007). GPA insecticide resistance involves multiple mechanisms. Thus, chemical control of the GPA population has little efficiency in the peach orchard management (Cravedi and Cervato 1997). In addition, the use of effective systemic insecticides such as imidacloprid has raised concerns in an increasing number of countries because of their possible non-targeted impact on beneficial insects (Decourtye et al. 2004; Peck 2009). Natural enemies as biological control means or novel approaches such as kaolin treatments has been alternatively proposed (Barker et al. 2007; Gentz et al. 2010). Host-plant resistance seems to be more promising as a long-term solution since it could contribute to a more sustainable integrated pest management. However, peach germplasm has been rarely tested for resistance to this insect pest. Some studies were performed on this topic at the INRA Bordeaux, France (Massonié et al. 1982; Monet and Massonié, 1994; Kfoury et al. 1995). Additional studies were carried out on the probing and settling behaviors of the GPA on selected cultivars at the INRA Avignon (Sauge et al. 1998a, 1998b, 2002, 2006). Five resistant genotypes were identified among which two peach cultivars, "Weeping Flower Peach" (S2678) and "Rubira" ${ }^{\circledR}$ "(S2605), showing strong antixenosis resistance (Massonié et al. 1982; Monet and Massonié 1994). This mechanism of resistance prevents plant colonization (Sauge et al. 1998b). It was linked with hypersensitive-like necrotic reactions that appeared on the apices within 2-3 days after the infestation in the kind of reddish or yellowish spots generally located at the puncture point. In addition, induced systemic resistance was demonstrated for "Rubira" (Kfoury and Massonié 1995; Sauge et al. 2002, 2006) and the possible involvement of phenolic compounds was suggested (Poëssel et al. 2002). A simple dominant genetic determinism was established for both "Weeping Flower Peach" (Monet and Massonié 1994) and "Rubira" (Pascal et al. 2002). The putative resistance gene in "Weeping Flower Peach" was named $R m l$ ( $R m$ for resistance to Myzus persicae) by Monet and Massonié (1994). However differences in the aphid behaviour suggested that the underlying resistance mechanism might be different in "Rubira" (Sauge et al. 1998b, 2002, 2006).

Following these studies, "Rubira" ${ }^{\circledR}$ " was selected as preferential GPA resistance source because of its higher agronomical potential and lower level of heterozygosity compared to the botanical cultivar "Weeping Flower Peach" . This might therefore limit variability in derived 
hybrid genotypes. An intra-specific $\mathrm{F}_{2}$ population, obtained from a cross between the susceptible rootstock peach "Pamirskij 5" and "Rubira" ${ }^{\circledR}$ " as pollen source, was grown and scored for GPA resistance. The aim of the present study was to build a SSR-based $\mathrm{F}_{2}$ map anchored to the "Texas" $\times$ "Earlygold" general map for Prunus referred to as T $\times$ E map (Genome Database for Rosaceae, http://www.rosaceae.org) and to map the induced GPA resistance carried by "Rubira" ${ }^{\circledR}$ ". The overall goal of our work is to subsequently develop reliable markers linked to the resistance locus in order to use "Rubira" ${ }^{\circledR}$ " as a genitor for introgressing resistance to GPA into peach cultivars of high agronomical value.

\section{Materials and methods}

\section{Plant material}

The $\mathrm{F}_{2}$ mapping population $(\mathrm{n}=187)$ was obtained from the selfing of a single individual derived from the controlled pollination of "Pamirskij 5" (clone S6146) by Rubira ${ }^{\circledR}$ (clone S2605). "Pamirskij 5" is a green-leaf rootstock peach (Prunus persica L. Batsch) derived from seeds obtained from the Nikita Botanical Garden of Yalta (Crimea, Ukraine); it is resistant to peach powdery mildew (Sphaerotheca pannosa) and susceptible to GPA. Rubira ${ }^{\circledR}$ is a red-leaf rootstock peach selected from peach seedlings grown at the INRA from a Californian seed lot imported in 1960; it is resistant to GPA and susceptible to powdery mildew. Resistance to powdery mildew and GPA are both dominant to susceptibility. The "Pamirskij 5" $\times$ "Rubira ${ }^{\circledR} " \mathrm{~F}_{2}$ population (hereafter referred to as $\mathrm{PR}^{2}$ ) also segregates for leaf color. This phenotypic trait is controlled by a single gene $(G r)$, red being dominant and green recessive (Blake 1937). "Rubira ${ }^{\circledR, " ~ i s ~ h o m o z y g o u s ~ f o r ~ b o t h ~ r e d ~ c o l o r ~ a n d ~ G P A ~ r e s i s t a n c e . ~}$

\section{Assessment of aphid-plant interactions}

Two phenotypic trials were carried out. The first one (Trial 1) was performed in a greenhouse under controlled conditions using an aphid colony established from a single GPA female (Mp03 clone) collected from a peach tree in 1997 in Avignon, Southern France. Mp03 apterous aphids were continuously reared on susceptible GF305 peach seedlings under parthenogenesis-inducing conditions $\left(19 \pm 1{ }^{\circ} \mathrm{C}\right.$; long-day photo period of L16:D8) in a growth chamber (Sauge et al. 1998b; 2002). Procedure and scoring method of trial 1 were similar to Pascal et al. (2002). After a 3-month stratification and radical emergence, 187 seeds derived from the selfing of the $\mathrm{F}_{1}$ parent were individually potted, placed in a greenhouse and maintained at $23 \pm 5^{\circ} \mathrm{C}$. After 3 months, once seedlings were $30-35 \mathrm{~cm}$ high, controlled infestations were achieved in April by placing two 5- to 7-day-old apterous adults of $M$. persicae on the terminal apex of each seedling. First plants were observed four times during 2 weeks (referred to Trial 1 stage 1). The last scoring dataset was kept for further analyses. Then a final control assessment was performed one month later (i.e. in May, referred to Trial 1 control). For both assessments, each plant was visually rated for (i) aphid colony development and (ii) leaf curling responses, These two parameters were scored separately using a well-tried linear ordinal scale from 0 (no aphid, no curling respectively) to 4 (all apices colonized by numerous aphid, all apices curled respectively). In addition the presence/absence of reddish necrotic spots was recorded using a binary score (i.e. 1/0).

The second trial (Trial 2) was conducted on the whole population, under reinforced natural conditions of infestation in the experimental field of "les Garrigues" at the INRA Avignon. Seedlings had been planted three years before on their own roots in rows $4.0 \mathrm{~m}$ apart and with a tree-to-tree distance of $0.5 \mathrm{~m}$. Trees were about $2 \mathrm{~m}$ high, blooming for the first time during 
the year of evaluation. Before and during Trial 2, orchard was treated with fertilizers but no insecticides and fungicides were applied. Naturally occurring aphids were allowed to infest the trees over the grooving season (April to June). Initial aphid infestation was assessed at least on two branches of each genotype by visual check. For peach trees showing little or no GPA infestation, aphids were collected from nearby peach trees and placed onto the apical part of the main shoots to reinforce natural conditions of infestation. Peach trees were assessed at the end of the grooving season. They were scored as resistant (no aphid colony and a small number of leaves weakly to moderately curled) or susceptible for the other cases. Necrotic spots were scored by using the same method as for Trial 1.

\section{DNA isolation}

Samples of young expanded terminal leaves from the parents and the 187 seedlings were collected in May 2006 and kept at $-80{ }^{\circ} \mathrm{C}$ until DNA isolation. Genomic DNA isolation was then performed following the protocol of Bernatzky and Tanksley (1986). DNA concentrations were measured using a spectrophotometer Thermo Scientific NanoDrop ${ }^{\mathrm{TM}}$. DNA quality was assessed by electrophoresis on $1 \%$ agarose gel.

\section{SSR analysis}

Publicly available Prunus SSR primer pairs (see Table 1) were tested for their polymorphism by using the protocol of Rubio et al. (2010). They were first screened by using the two parents, then a set of eight individuals of the population when it was necessary for establishing segregation patterns. Segregating SSRs with easily readable profiles were then selected from their position in the $\mathrm{T} \times \mathrm{E}$ map or in other published Prunus maps, and mapped in the whole population using the multiplex protocol.

\section{Multiplex protocol and genotyping}

The whole population was amplified by using the QIAGEN ${ }^{\circledR}$ Multiplex PCR Kit (Qiagen Inc. Valencia, Ca) with 2 to 6 primer pairs simultaneously $(0.2$ and $0.4 \mu \mathrm{M}$ concentration for each IRD700 and IRD800 labeled primers respectively) with 2x QIAGEN multiplex PCR master mix (final concentration $1 \times$ ) and $5 \times$ of Q-Solution (final concentration $0.5 \times$ ). The same concentration was used for the complementary primers. Ten ng of genomic DNA were used in a final reaction volume of $10 \mu \mathrm{l}$. DNA amplifications were carried out in a Mastercycler ${ }^{\circledR} \mathrm{ep}$ gradient thermal cycler (Eppendorf $\mathrm{GmbH}$, Germany) using the universal multiplex cycling protocol (QIAGEN Multiplex PCR kit; QIAGEN): $15 \mathrm{~min}$ at $95{ }^{\circ} \mathrm{C}$ (initial denaturation step) followed by 35 cycles consisting of $94{ }^{\circ} \mathrm{C}$ for $30 \mathrm{~s}, 57{ }^{\circ} \mathrm{C}$ for $90 \mathrm{~s}$, and $72{ }^{\circ} \mathrm{C}$ for $60 \mathrm{~s}$, with a final extension of $10 \mathrm{~min}$ at $72{ }^{\circ} \mathrm{C}$. The PCR products were then diluted in formamide blue in a 1:40 ratio and denatured at $95^{\circ} \mathrm{C}$ for $3 \mathrm{~min}$. Then, $0.5-0.8 \mu \mathrm{l}$ of each sample was loaded on a $6 \%$ polyacrylamide sequencing gel and run at constant power $(1,500 \mathrm{~W})$ for $1-2$ hours using a LI-COR (IR2) sequencer (Model 4200, LI-COR; Nebraska).

\section{Segregation analysis and map bulding}

Departures from the 1:2:1 or 3:1 ratios expected for a $F_{2}$ population were tested by using chisquare goodness-of-fit on segregation data. Linkage analysis was performed using MAPMAKER/EXP V3.0 software (Lincoln et al. 1992). Linkage groups (G) were initially established by using a critical logarithm of the odds (LOD) threshold of 8.0 and a recombination fraction of 0.30 . Marker distances were calculated using the Kosambi mapping function (Kosambi 1944). After mapping, the "error detection" option of Mapmaker was used 
to detect possible errors. Map figures were obtained by using MapChart software (Voorrips et al. 2002).

\section{QTL analysis and mapping of GPA resistance, necrotic reactions and Gr gene}

In first approach, a single-gene inheritance model was applied for GPA resistance. The quantitative Trial 1 control dataset was transformed according to a binary distribution (resistant/susceptible). Seedlings scored 0 to 1 for both colony development and leaf curling were considered resistant whereas others were considered susceptible. Plants scored up to 2 for leaf curling were nevertheless considered resistant when no aphid was observed and necrosis spots were clearly visible. Three binary datasets were then used for mapping GPA resistance: (i) the transformed Trial 1 control dataset (ii) Trial 2 dataset. (iii) Final dataset (thereafter referred to as FD) which corresponds to the genotypes common to both trials. These datasets were added to the marker dataset used for map construction after coding as defined in MAPMAKER/EXP V3.0 for dominant markers. The presence of necrotic spots was accordingly mapped.

Then, in order to ascertain the single-gene inheritance of the resistance, QTL detection was performed by composite interval mapping (CIM) (Zeng 1994) with MapQTL 5.0 software (Van Ooijen et al. 2004) using the quantitative datasets of Trial 1, independently for colony development and leaf curling. Moreover, since distributions heavily departed from normality and particularly for colony development, a non-parametric test based on the Kruskal-Wallis (KW) methodology (Kruglyak and Lander 1995) was performed using the same software; as recommended by Van Ooijen et al. (2004) a stringent association level of 0.005 (P-value) was chosen. For CIM, the most appropriate LOD threshold to declare a QTL putative (type-I error $\alpha=0.05$ ) was estimated by using the 1000-permutation test. The percentage of phenotypic variation explained was estimated for each QTL.

In addition, each seedling was scored for leaf color (red/green) according to a binary distribution (1/0 respectively). The dominant $G r$ gene responsible for leaf color was then mapped with the same way for GPA resistance.

\section{Results}

\section{Linkage map construction}

One hundred eighty-seven progenies were used for map construction. The 120 SSR loci and the two phenotypic traits, $R m 2$ and $G r$, mapped to seven linkage groups instead of the eight expected in Prunus, at a LOD score of 19.0. Six of the groups (Fig. 1) were homologous to six groups of the $\mathrm{T} \times \mathrm{E}$ map (G1, G2, G3, G4, G5 and G7). The remaining one was composed of the dominant $\mathrm{Gr}$ gene and thirty-five SSR markers (Fig. 2) among which 17 located to G6 and 14 to G8 in published Prunus maps. This pseudo-linkage between G6 and G8 suggested a reciprocal translocation between the corresponding chromosomes in one of the parents of the $\mathrm{PR}^{2}$ population. In order to separate the two groups, two sets of markers which unambiguously mapped to G6 or G8 in published Prunus maps were selected and independently mapped. Among the four remaining markers, three mapped to different groups in Prunus maps (BPPCT042C, EPPCU4962B and EPPB4213B) and one (MA023a) at two possible loci (MA023aA in G6 or MA023aB in G8 in the T $\times$ E bin-map). Three among them (EPPCU4962B, EPPB4213B, MA023aA/B) mapped with similar LOD to G6 and G8. They 
were finally assigned to one of the group (Fig. 2) by blasting the respective primer pair sequences onto the peach genome sequence v1.0 (http://www.rosaceae.org/peach/genome). The most likely position of the translocation was estimated by testing each marker of G6 against G8 framework and reciprocally by using the "try" command (Fig. 2).

The $\mathrm{PR}^{2}$ map covered a total distance of $497.8 \mathrm{cM}$ (Fig. 1). Three among the $116 \mathrm{SSR}$ primer pairs used for mapping revealed several loci: BPPCT019 amplified three loci (on G1, G7 and G8) whereas EPPCU4962 and UDP96-015 amplified two loci (on G5 and G8, G7 and G8 respectively). They were named according to the general nomenclature. Seven loci were not previously mapped: BPPCT019C (G1), UDAp-471 (G2), BPPCT042C (G6), EPPB4213B and EPPCU4962B (G8), UDAp-444 and UDP96-015B (G7). Seven SSR markers (BPPCT019A, B and C, AMPA109, BPPCT013, ECU4962A and UDAp-444) and the two phenotypic markers were scored dominant. Sixteen SSRs in total $(13.3 \%)$ deviated significantly from their chi-square expectations for the 1:2:1 ratio $(\mathrm{P}<0.1)$ : 5 were in $\mathrm{G} 2,11$ were in $\mathrm{G} 6$ or $\mathrm{G} 8$ in the interval comprising or flanking the translocation region (Fig. 1). In G6 and G8, the deviation was due to an excess of heterozygous individuals $(61.4 \%$ and $59.8 \%$ on average respectively) linked to a lack of homozygous individuals for the "Rubira" ${ }^{\circledR}$ " allele $(13.7 \%$ and $15 \%$ on average respectively). In G2, it was the opposite: the excess of heterozygous individuals $(58.7 \%)$ was linked to a lack of homozygous individuals for the "Pamirskij 5" allele $(14.1 \%)$. Forty-four SSR loci $(37 \%)$ were common with the $\mathrm{T} \times \mathrm{E}$ map. The map coverage was estimated to $87 \%$ of the $\mathrm{T} \times \mathrm{E}$ map by using the information derived from published Prunus maps with some disparities (from nearly 100\% for G1 and G6 to $48 \%$ for G3). The number of loci mapped to each linkage group ranged from 10 (G5) to 19 (G1, G6) with an average of 15. The length of each linkage group was comprised between $98.7 \mathrm{cM}$ (G1) and $35.4 \mathrm{cM}(\mathrm{G} 3)$ The average distance between loci ranged from $3.2 \mathrm{cM}$ (G3) to 5.8 cM (G1) with an overall average distance of $4.1 \mathrm{cM}$. Three gaps longer than $15 \mathrm{cM}$ were observed in three of the eight linkage groups (G1, G3 and G5).

\section{Phenotypic assessment of resistance to GPA}

One hundred sixty-six plants were tested in greenhouse conditions (Trial 1). The remaining ones (21) were not subjected to GPA infestation owing to insufficient development. Two weeks after infestation (Trial 1 stage 1), aphids had left 120 seedlings (72.3\%) and one GPA remained on each of 5 additional ones. All of them showed clearly visible reddish necrotic spots. GPA colonization score was 2.4 on average for the 41 remaining ones (range 1.5-3). One hundred and seventeen seedlings $(70.5 \%)$ showed various levels of leaf curling (score range 0.5 to 3.75 ). The average score was 0.61 for the 120 seedlings showing no GPA and 2.32 for the others. One month later (Trial 1 control), the 125 seedlings showing necrotic spots housed no GPA (75.3\%). The 41 remaining seedlings showed important colony development (average score 3.74) and leaf curling (average score 3.72 comparatively to 0.31 for those considered resistant). As expected, data were on the whole not normally distributed and particularly for aphid colonization (Fig 3).

In Trial 2, the whole population (187) was assessed in orchard conditions: 136 (75.8\%) were scored resistant, 43 susceptible $(24.2 \%)$ and 8 missing data. In the latter no GPA was observed as well as no necrotic spot whereas very light leaf curling was detected. This suggests escape from GPA infestation. Altogether, 165 genotypes were common to both trials and thus assessed in both conditions: 123 were scored resistant (74.5\%) and 42 susceptible (25.5\%). The associated dataset is thereafter referred to as FD (for final dataset). Complete association was observed between resistance and presence of necrotic reactions in both trials. 
These results agree with the 3:1 segregation ratio expected in a $\mathrm{F}_{2}$ population for a dominant trait $\left(\chi^{2}=0.008,0.018\right.$ and 0.09 for Trial 1, Trial 2 and FD respectively) and are thus in agreement with a single-gene model of inheritance of the GPA resistance for "Rubira ${ }^{\circledR, "}$.

\section{Mapping of GPA resistance and QTL analysis}

The putative resistance gene was mapped as a dominant marker using the binary datasets issued from Trial 1, Trial 2 and FD. The gene positions computed for each of them were distributed over a $2.5 \mathrm{cM}$ interval between pchgms29 and UDAp-467 markers at the bottom end of G1 as well as for the "necrotic spot" trait. The consensus position in the PR ${ }^{2}$ map was determined by using FD (Fig. 1).

With KW test (Table 2) the strongest association was detected with UDAp-467 for colonization $\left(K=134.2 ; P<10^{-9}\right)$ as well as for leaf curling $\left(K=80.1 ; P<10^{-9}\right)$. An additional marker at the bottom of G7, CPPCT017, was found significantly associated with leaf curling $\left(\mathrm{K}=13.8 ; P=2 \times 10^{-3}\right)$.

With CIM, a major QTL was detected in the same region as for KW for colonization as well as for leaf curling (Table 2) and was co-located with the dominant locus. The phenotypic variations explained were $80.9 \%$ and $74 \%$ respectively. We therefore propose to name $R m 2$ both QTL and dominant locus in reference to $R m 1$ gene. An additional QTL was detected for leaf curling in the same region of G7 as for KW. The additive effects showed that "Rubira" carried the unfavorable allele (Table 2). However, as the computed LOD threshold was 2.62, it was only significant for KW. This putative QTL (Curl-PR $\left.{ }^{2}-7.1\right)$ was named according to the trait name, the mapping population, the linkage group and a number.

\section{Mapping of the Gr gene}

Forty-height seedlings had green foliage in the mapping population $(25.7 \%)$ which is in accordance with the $3: 1$ segregation ratio expected for a dominant character $\left(\chi^{2}=0.088\right)$. The 139 other ones were homozygous for the red color of the leaves or heterozygous. The $G r$ gene mapped in the middle of G6 slightly above CPSCT012 (Fig 1).

\section{Discussion}

\section{$P R^{2}$ genetic map}

Peach is genetically the best characterized species in the genus Prunus. However, only few genetic maps derived from modern peach cultivars are available owing to the low degree of polymorphism generally observed due to the narrow genetic base (Rajapakse et al. 1995; Dirlewanger et al. 2006). Most of the published maps were built by using rootstock peach cultivars or cultivars having divergent breeding histories (Yamamoto et al. 2005; Ogundwin et al. 2009). The other maps involving a peach cultivar were derived from interspecific crosses (Jáuregui et al. 2001; Aranzana et al. 2003; Foulongne et al. 2003a; Verde et al. 2005; Blenda et al. 2007; Marandel et al. 2009). In this study, we constructed a $F_{2}$ SSR-based genetic map derived from two rootstock peach cultivars of different origins in order to take advantage of the genetic backgrounds from which they were issued. Since a pattern of complete synteny was demonstrated for all studied Prunus species (Arús et al. 2005) the use of SSRs enabled for easy cross-referencing of marker and trait locus positions with the $\mathrm{T} \times \mathrm{E}$ map (Genome database for rosaceae: http://www.rosaceae.org), numerous published Prunus 
maps (Dirlewanger et al. 2004 and 2006; Yamamoto et al. 2005; Verde et al. 2005; Howad et al. 2005; Dondini et al. 2007; Rubio et al. 2010) and the peach genome sequence (http://www.rosaceae.org/peach/genome). This allowed for identifying of a reciprocal translocation between the chromosomes corresponding to G6 and G8 in the PR ${ }^{2}$ map and to correctly assign markers to their respective groups. Reciprocal translocations have already been reported in previous studies for populations derived from parents contrasting for leafcolor: the interspecific "Garfi" almond × "Nemared" peach population (Jauregui et al. 2001; Dirlewanger et al. 2004) and the intraspecific peach "Akame" $\times$ "Juseitsou" population (Yamamoto et al. 2005) in which "Nemared" and "Akame" are the red-leaf cultivars. They were identified in similar map positions close to the $G r$ gene (Jauregui et al. 2001; Dirlewanger et al. 2004). Jauregui et al. (2001) suggested that "Nemared" might be a moreprobable candidate for the translocation. In "Nemared", the red-leaf character was reported to come from "Bound Brook" which derives from Tennessee naturals, one of the first peach germplasm introduced in the USA, and genetically different from the most-wide spread peach germplasm (Hesse 1975). Based on the results of the current study and on those obtained with crosses between "Pamirskij 5" and another green-leaf peach cultivar (data not published) we confirm that "Rubira ${ }^{\circledR, " ~ c a r r i e s ~ t h e ~ r e a r r a n g e m e n t . ~ A l s o, ~ w e ~ s u g g e s t ~ t h a t ~ t h e ~ l a t t e r ~ c o u l d ~}$ probably have the same origin for the three red-leaf cultivars.

Only few differences in locus order were observed between the $\mathrm{PR}^{2}$ map and the Prunus maps. In G5, AMP105, PacD30 and BPPCT026 co-located in the GN22 map (Dirlewanger et al. 2004) whereas they were comprised in a $26.6 \mathrm{cM}$ interval in the $\mathrm{PR}^{2}$ map. This is probably due to the important degree of segregation distortion observed in the GN22 map (41.5\%). In G3, UDP-403 and BPPCT007 mapped at inverted position in the $\mathrm{T} \times \mathrm{E}$ map, probably due to the difference in population size. Again, this confirms synteny in Prunus species (Arús et al. 2005). Seven SSRs mapped at new loci compared to the other maps. The positions of all the other markers mapped in the $\mathrm{T} \times \mathrm{E}$ bin-map (Howad et al. 2005) were consistent with their locations in the $\mathrm{PR}^{2}$ map. This confirms the relevance of the bin-mapping method for new markers, although the peach genome sequence is now a more practical tool.

\section{Resistance to GPA}

The experimental device used in this study was established to assess the $\mathrm{PR}^{2}$ population in contrasted conditions and thus clearly ascertain the resistant $v s$ susceptible status of each progeny. Seedlings were thereby planted on their own roots to prevent genotype-rootstock interactions. They were observed in two different environments and resistance was assessed both at the young and grown-up stage. In addition, two unrelated GPA populations were used. In resistant-scored genotypes, most aphids (i.e. GPA) left the plants within the first week following infestation and for half of them within the first two days, as previously reported by Sauge et al. (1998b) for "Rubira" ${ }^{\circledR}$ ". The latter indeed exhibits antixenosis causing a dissuasive effect of GPA settlement for adult and nymph stadium. This dissuasive effect enables the identification of genotypes carrying resistance in the $\mathrm{PR}^{2}$ population. GPA resistance was also shown to be linked with hypersensitive-like necrotic reactions. This suggests that they might be governed by the same mechanism, but also allows confirming resistance. Consequently, a simple rating scale with two classes, resistant and susceptible, could have been used to score the plants, as reported in other aphid resistance studies (Klingler et al. 2005; Hill et al.2006; Bus et al. 2008; Evans et al. 2008), because only the two distinctive parental phenotypes were observed in the segregating population. This was confirmed with the QTL analysis as the qualitative resistance locus and the QTL peak mapped to the same region of the $\mathrm{PR}^{2}$ map whatever the method and the environmental conditions. For leaf curling, despite data distributions suggested that several QTLs could have been involved, the same QTL as for resistance to colonization was identified suggesting that no specific genomic region was 
involved. Leaf curl injuries are indeed a consequence of aphid punctures, sap ingestion and interaction of salivary products with cell wall elements of the leaves. They are therefore linked to the number of aphids feeding on the plant. This explains why the same major QTL region was identified for both traits. An additional QTL was nevertheless identified in G7 but its effect and significance level were too low to draw a firm conclusion.

These findings demonstrate consistency of the results and the single-gene inheritance previously demonstrated by Pascal et al. (2002) for resistance to colonization in "Rubira ${ }^{\circledR}$ ". A similar GPA resistance gene ( $R m 1$ ) was reported by Monet and Massonié (1994) in "Weeping Flower Peach", but to date, its genomic position as well as its nature is unknown. Sauge et al. $(2002,2006)$ demonstrated significant differences in the aphid behavior between these two cultivars. In "Rubira ${ }^{\circledR}$,, plant resistance is induced by the feeding punctures and evolves even in the absence of aphids, after a short initiation stage followed by a latency period. It is systemic and disappears $48 \mathrm{~h}$ after aphid removal as demonstrated by Kfoury and Massonié (1995). Moreover, previous infestation dramatically increases the expression of antixenotic host plant resistance as indicated by its strong negative impact on the GPA settlement (Sauge et al. 2002). In contrast, no induced resistance was observed in "Weeping Flower Peach" as well as no modification in the level of resistance (Sauge et al. 2006). We have consequently hypothesized that these genes might be different and proposed naming $R m 2$ the dominant allele responsible for GPA resistance in "Rubira ${ }^{\circledR}$ ". However, this point would have to be settled in future studies.

Contrary to peach for which only two studies are available on the genetic determinism of GPA resistance (Monet and Massonié 1994; Pascal et al. 2002), there are many examples of dominant genes conferring monogenic resistance to aphids. These genes were identified in a wide range of annual crops such as the model-legume Medicago truncatula Gaert (Klingler et al. 2005, 2007; Gao et al. 2008), soybean (Hill et al. 2006; Li et al. 2007), tomato (Rossi et al. 1998; Goggin et al. 2004), melon (Dogimond et al. 2004), lettuce (Wroblewski et al. 2007) or wheat (Liu et al. 2005). In the Rosaceae family, several genes were identified in apple (Cevik et al. 2002; Bus et al. 2008; 2010) or pear (Evans et al. 2008). Analysis of those that were characterized has shown strong homology or tight linkage with genes which encode members of the large nucleotide-binding site leucine-rich repeat (NBS-LRR) resistance protein family (Milligan et al. 1998; Cevik et al. 2002; Dogimond et al. 2004; Klingler et al. 2005, 2007; Gao et al. 2008; Tagu et al. 2008). Moreover, studies about the non-persistent transmission of plum pox potyvirus demonstrated that $M$. persicae was a poor vector in "Rubira" (Fos and Massonié 1993). Similar difficulties to transmit non-persistent virus were reported for the aphid Aphis gossypii in melon accessions carrying the Vat gene, a member of the CC-NBSLRR gene family which confers resistance to this aphid (Pitrat and Lecoq 1980). Without prejudice on mechanisms involved in GPA resistance, these findings strongly suggest that $R m 2$ is also a member of the NBS-LRR family and give clues for gene discovery. Candidate gene searches on this family would be a valuable option in first approach using published resistance genes analogs (RGAs) sequences and the peach genome sequence (http://www.rosaceae.org/peach/genome) like primary resources. In peach, several authors reported the identification of loci conferring pest or pathogen resistance (Yamamoto et al. 2002b; Foulongne et al. 2003b; Dirlewanger et al. 2004; Decroocq et al. 2005; Lalli et al. 2005; Marandel et al. 2009) and few of these identified and mapped RGAs for the most part focused on PPV resistance. Among these authors, Lalli et al. (2005) generated a resistance map for Prunus based on candidate genes representing various classes of resistant genes; three of them, Cd77, C5 and D5 (GenBank accession $\mathrm{N}^{\circ}$ CZ445406, CZ445424 and CZ445426 respectively) hit close to the GPA resistance region. The first one, a NBS-like RGA, has already been mapped in the same region of apricot by Lambert et al. (2007); the others developed from a peach "Nemared" BAC library belong to the TIR-NBS-LRR class. 
They were initially mapped in other groups by Lalli et al. (2005), but the comparison of their sequences with the peach genome sequence v1.0 demonstrated a main assignment to the bottom end of scaffold 1 (G1) in the interval between EMPA011 and UDP-022. However, a rough analysis of the genes that were annotated in the GPA resistance region has revealed the presence of numerous additional genes that belong to the NBS-LRR family or coding for various R proteins. They could equally be considered candidates for GPA resistance.

The use of single-gene based resistance has often been controversial since it has been shown to be an ineffective approach to achieving durable resistance. Indeed, most of the resistance genes have been overcome such as the $\mathrm{Mi}-\mathrm{I}$ gene for aphid and nematode resistance in tomato (Rossi et al 1998) or several genes involved in apple scab, powdery mildew, fire blight, and woolly apple resistance in apple (Bus et al. 2010). This concern has been taken into account at the INRA Avignon and several strategies have been straightaway considered (Lambert et al. 2008). For instance, the combination with other single-gene resistance such as that from "Weeping Flower Peach" if demonstrated different, or with quantitative antibiosis-based resistance such as that derived from $P$. davidiana P1908 (Massonié et al. 1982; Sauge et al. 1998b) for which QTLs for resistance have been identified (Sauge et al. 2004). The combination of both antixenosis and antibiosis in improved genotypes would be more difficult to overcome and thus would increase durable resistance in a context of sustainable aphid management programs.

\section{Conclusion}

In this study we have mapped for the first time a gene $(R m 2)$ conferring dominant resistance to GPA in peach. Rm2 will be very useful in the development of new peach cultivars combining several types of aphid resistance in improved genotypes with the aim of durable resistance or with gene pyramids for multiple resistances. The identification of DNA markers tightly linked with $R m 2$ would increase the efficiency of selection for resistant plants in segregating populations through marker-assisted breeding methods (MAB). This would be facilitated by the use of the peach genome sequence (Genome Database for Rosaceae http://www.rosaceae.org).

\section{Acknowledgements}

The authors acknowledge A. Bachellez, E. Lecerf and X. Titeca for technical assistance and the International Peach Initiative Consortium (IPGI) for the early release of the peach genome sequence v1.0. All experiments described in this paper comply with the current laws in the European Union.

\section{References}

Aranzana MJ, Garcia-Mas J, Carbó J, Arús P (2002) Development and variability analysis of microsatellite markers in peach. Plant Breed 121:87-92

Aranzana MJ, Pineda A, Cosson P, Dirlewanger E, Ascasibar J, Cipriani G, Ryder CD, Testolin R, Abbott A, King GJ, Iezzoni AF, Arús P (2003) A set of simple-sequence repeat (SSR) markers covering the Prunus genome. Theor Appl Genet 106:819-825

Arús P, Yamamoto T, Dirlewanger E, Abbott AG (2005) Synteny in the Rosaceae. In: Janick J (ed) Plant Breeding Reviews. John Wiley and Sons Inc, USA, pp 175-211

Barker E, Holaschke M, Fulton A, Evans K Powell G (2007) Effects of kaolin particle film on Myzus persicae (Hemiptera: Aphididae) behaviour and performance. Bulletin of Entomological Research (2007), 97:455460

Bernatzky R, Tanksley SD (1986) Genetics of actin-related sequences in tomato. Theor Appl Genet 72:314-321

Blake MA (1937) Progress in peach breeding. Proc Am Soc Hortic Sci 35:49-53 
Blackman RL, Eastop VF (2000) Aphids on the World's Crops. An identification and information guide. 2nd ed. John Wiley \& Sons, Chichester

Blenda A, Verde I, Georgi L, Reighard G, Forrest S, Muñoz-Torres M, Baird W, Abbott, A (2007) Construction of a genetic linkage map and identification of molecular markers in peach rootstocks for response to peach tree short life syndrome. Tree Genet Genomes 3:341-350

Bus VGM, Chagné D, Basset HCM, Bowatte D, Calenge F, Celton JM, Durel CE, Malone MT, Patocchi A, Ratanunga AC, Rikkerink AHA, Tustin DS, Zhou J, Gardiner SE (2008) Genome mapping of three major resistance genes to wooly apple aphid (Eriosoma lanigerum Hausm.). Tree Genet Genomes 4:223-236

Bus VGM, Bassett HCM, Bowatte D, Chagné D, Ranatunga CA, Ulluwishewa D, Wiedow C, Gardiner SE (2010) Genome mapping of an apple scab, a powdery mildew and a woolly apple aphid resistance gene from open-pollinated Mildew Immune Selection. Tree Genet Genomes 6:477-487

Cantini C, Iezzoni AF, Lamboy WF, Boritzki M, Struss D (2001) DNA fingerprinting of tetraploid cherry germplasm using SSRs. J Am Soc Hort Sci 126:205-209

Cevik V, King GJ (2002) High resolution genetic analysis of the $S d-1$ aphid resistance locus in Malus spp. Theor Appl Genet 105:346-354

Clarke JB, Tobutt KR (2003) Development and characterization of polymorphic microsatellites from Prunus avium "Napoleon". Mol Ecol Notes 3:578-580

Cipriani G, Lot G, Huang WG, Marrazzo MT, Peterlunger E, Testolin R (1999) AC/GT and AG/CT microsatellite repeats in peach [Prunus persica (L) Batsch]: isolation, characterisation and cross-species amplification in Prunus. Theor Appl Genet 99:65-72

Cravedi P, Cervato P (1997) Resistance to insecticides of the green peach aphid and Integrated Fruit Production guidelines. IOBC Bulletin 20(6):75-77

Decourtye A, Armengaud C, Renou M, Devillers J, Cluzeau S (2004). Imidacloprid impairs memory and brain metabolism in the honeybee (Apis mellifera L.). Pestic. Biochem. Phys 78:83-92

Decroocq V, Favé MG, Hagen L, Bordenave L, Decroocq S (2003) Development and transferability of apricot and grape EST microsatellite markers across taxa. Theor Appl Genet 106:912-922

Decroocq V, Foulongne M, Lambert P, Le Gall P, Mantin C, Pascal T, Schurdi-Levraud V, Kervella J (2005) Analogues of virus resistance genes map to QTLs for resistance to sharka disease in Prunus davidiana. Mol Gen Genomics 272:680-689

Devonshire AL, Field LM, Foster SP, Moores GD, Williamson MS, Blackman LR (1998). The evolution of insecticide resistance in the peach-potato aphid, Myzus persicae. Philos. Tran. R. Soc. Lond. B 353:16771684

Dirlewanger E, Cosson P, Tavaud M, Aranzana MJ, Poizat C, Zanetto A, Arús P, Laigret F (2002) Development of microsatellite markers in peach [Prunus persica (L.) Batsch] and their use in genetic diversity analysis in peach and sweet cherry (Prunus avium L.). Theor Appl Genet 105:127-138

Dirlewanger E, Cosson P, Howad W, Capdeville G, Bosselut N, Claverie M, Voisin R, Poizat C, Lafargue B, Baron O (2004) Microsatellite genetic linkage maps of myrobalan plum and an almond-peach hybridlocation of root-knot nematode resistance genes. Theor Appl Genet 109:827-838

Dirlewanger E, Cosson P, Boudehri K, Renaud C, Capdeville G, Tauzin Y, Laigret F, Moing A (2006) Development of a second-generation genetic linkage map for peach [Prunus persica (L.) Batsch] and characterization of morphological traits affecting flower and fruit. Tree Genet Genomes 3:1-13

Dogimont CA, Bendahmane A, Pitrat M, Burget-Bigeard, Hagen L, Le Menn A, Pauquet J, Rousselle P, Caboche M, Chovelon V (2004) Gène de résistance à Aphys gossypii. World patent WO2004072109.

Dondini L, Lain O, Geuna F, Banfi R, Gaiotti F, Tartarini S, Bassi D, Testolin R (2007) Development of a new SSR-based linkage map in apricot and analysis of synteny with existing Prunus maps. Tree Genet Genomes 3:239-249

Downey LD, Iezzoni AF (2000) Polymorphic DNA markers in black cherry are identified using sequences from sweet cherry, peach, and sour cherry. J Am Soc Hort Sci 125:76-80 
Evans K, Govan CL, Fernández-Fernández F (2008) A new gene for resistance to Dysaphis pyri in pear and identification of flanking microsatellite markers. Genome 51:1026-1031

Fos A, Massonié G (1993) Transmission expérimentale du virus de la sharka par Brachycaudus persicae Passerini. Agronomie (13)6:515-518

Foster SP, Devine G, Devonshire AL (2007) Insecticide resistance, pp. 261-285. In H. F. van Emden and R. Harrington [eds.], Aphids as crop pests. CABI, Oxfordshire, United Kingdom

Foulongne M, Pascal T, Arús P, Kervella J (2003a) The potential of Prunus davidiana for introgression into peach [Prunus persica (L.) Batsch] assessed by comparative mapping. Theor Appl Genet 107:227-238

Foulongne M, Pascal T, Pfeiffer F, Kervella J (2003b) QTLs for powdery mildew resistance in peach $\times$ Prunus davidiana crosses: consistency across generations and environment. Mol Breed 12:33-50

Gao L, Klingler JP, Anderson JP, Edwards OR, Singh KB (2008) Characterization of Pea aphid resistance in Medicago Truncatula. Plant Physiol 146:996-1009

Gentz MC, Murdoch G, King GF (2010) Tandem use of selective insecticides and natural enemies for effective, reduced-risk pest management. Biological Control 52:208-215

Goggin FL, Shah G, Williamson VM, Ullman DE (2004) Developmental regulation of $M i$-mediated aphid resistance is independent of Mi-1.2 transcript levels. Mol Plant Microbe Interact 17:532-536.

Hagen LS, Chaib J, Fady B, Decroocq V, Bouchet JP, Lambert P, Audergon JM (2004) Genomic and cDNA microsatellites from apricot (Prunus armeniaca L.). Mol Ecol Notes 4:742-745

Hesse CO (1975) Peaches. In: Jannick J. Moore JN (ed) Advances in fruit breeding. Purdue University Press, West Lafayette, Indiana, pp 285-335

Hill CB, Li Y, Hartman GL (2006) A single dominant gene for resistance to the Soybean Aphid in the soybean cultivar Dowling. Crop Sci 46:1601-1605

Howad W, Yamamoto T, Dirlewanger E, Testolin R, Cosson P, Cipriani G, Monforte AJ, Georgi L, Abbott AG, Arus P (2005) Mapping with a few plants: using selective mapping for microsatellite saturation of the Prunus reference map. Genetics 171:1305-1309

Jáuregui B, de Vicente MC, Messeguer R, Felipe A, Bonnet A, Salesses G, Arús P (2001) A reciprocal translocation between "Garfi' " almond and "Nemared" “ peach. Theor Appl Genet 102:1169-1176

Joobeur T, Periam N, de Vicente MC, King GJ, Arús P (2000) Development of a second generation linkage map for almond using RAPD and SSR markers. Genome 43:649-655

Kervella J, Pascal T, Pfeiffer F, Dirlewanger E (1998) Breeding for multiresistance in peach tree. Acta Hort 465:177-184

Kfoury L, Massonié G (1995) Caractéristiques de la résistance du cultivar de pêcher Rubira® à Myzus persicae Sulzer. Agronomie vol. 15, 5:277-284

Klingler J, Creasy R, Gao L, Nair RM, Calix AS, Spattford Jacob H, Edwards OR, Singh KB (2005) Aphid resistance in Medicago truncatula involves antixenosis and phloem-specific, inducible antibiosis, and maps to a single locus flanked by NBS-LRR resistance gene analogs. Plant Physiology 137:1445-1455

Klingler J, Edwards OR, Singh KB (2007) Independant action and contrasting phenotypes of resistance genes against spotted alfalafa aphid and bluegreen aphid in Medicago truncatula. New Phytol 173:630-640

Kosambi DD (1944) The estimation of map distance from recombination values. Ann Eugen 12:172-175

Kruglyak L, Lander ES (1995) A non-parametric approach for mapping quantitative trait loci. Genetics 139:1421-1428

Lalli DA, Decroocq V, Blenda AV, Shurdi-Levraud V, Garay L, Le Gall O, Damsteegt V, Reighard GL, Abbott AG (2005) Identification and mapping of resistance gene analogs (RGAs) in Prunus: a resistance map for Prunus. Theor Appl Genet (2005) 111:1504-1513

Lambert P, Dicenta F, Rubio M, Audergon JM (2007) QTL analysis of resistance to sharka disease in the apricot (Prunus armeniaca L.) 'Polonais' x 'Stark Early Orange' F1 progeny. Tree Genetics \& Genomes 3:299-309

Lambert P, Sauge MH, Poëssel JL, Pascal T (2008) Pyramiding mono and polygenic resistances is one strategy to provide lasting control of the resistance to the green peach aphid and Powdery Mildew in peach. Fourth Rosaceae Conference, Pucon, Chile, 16-19 March 2008 
Li Y, Hill C, Carlson S, Diers B \& Hartman G (2007) Soybean aphid resistance genes in the soybean cultivars Dowling and Jackson map to linkage group M. Molecular Breeding 19:25-34

Lincoln SE, Daly MJ, Lander ES (1992) Constructing genetic maps with Mapmaker/exp 3.0, 3rd edn. Whitehead Institute Technical Report, Cambridge, Mass

Liu XM, Smith CM, Friebe BR, Gill BS (2005) Molecular Mapping and Allelic Relationships of Russian Wheat Aphid-Resistance Genes. Crop Sci 45 (6): 2273-2280

Lopes MS, Sefc KM, Laimer M, Da Câmara Machado A (2002) Identification of microsatellite loci in apricot. Mol Ecol Notes 2:24-26

Marandel G, Pascal T, Candresse T, Decroocq V (2009) Quantitative resistance to Plum pox virus in Prunus davidiana P1908 linked to components of the eukaryotic translation initiation complex. Plant Pathol 58:425435

Massonié G, Maison P, Monet R, Grasselly C (1982) Résistance au puceron vert du pêcher, Myzus persicae Sulzer (Homoptera : Aphididae) chez Prunus persica (L) Batsch et d'autres espèces de Prunus. Agronomie 2:63-70

Mazzoni E, Cravedi P (2002) Analysis of insecticide-resistant Myzus persicae (Sulzer) populations collected in Italian peach orchards. Pest Manag Sci 58:975-980

Messina R, Lain O, Marrazzo MT, Cipriani G, Testolin R (2004) New set of microsatellite loci isolated in apricot. Mol Ecol Notes 4:432-434

Milligan SB, Bodeau J, Yaghoobi J, Kaloshian I, Zabel P, Williamson VM. (1998) The root-knot nematode resistance gene $M i$ from tomato is a member of the leucine zipper, nucleotide binding, leucine-rich repeat family of plant genes. Plant Cell 10:1307-1319.

Mnejja M, Garcia-Mas J, Howad W, Badenes ML, Arús P (2004) Simple-sequence repeat (SSR) markers of Japanese plum (Prunus salicina Lindl.) are highly polymorphic and transferable to peach and almond. Mol Ecol Notes 4:163-166

Mnejja M, Garcia-Mas J, Howad W, Arús P (2005) Development and transportability across Prunus species of 42 polymorphic almond microsatellites. Mol Ecol Notes 5:531-535

Monet R, Massonié G (1994) Déterminisme génétique de la résistance au puceron vert (Myzus persicae) chez le pêcher. Résultats complémentaires. Agronomie 2:177-182

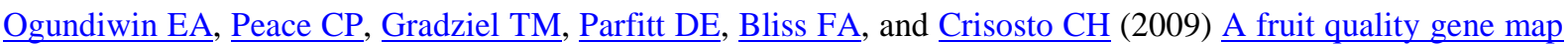
of Prunus. BMC Genomics 10:587

Pascal T, Pfeiffer F, Kervella J, Lacroze JP, Sauge MH (2002) Inheritance of green peach aphid resistance in the peach cultivar "Rubira®". Plant Breeding 121: 459-461

Peck DC (2009) Long-term effects of imidacloprid on the abundance of surface and soil-active nontarget fauna in turf. Agricultural and Forest Entomology 11:405-419

Pitrat M, Lecoq H (1980) Inheritance of resistance to Cucumber mosaic virus transmission by Aphis gossypii in Cucumis melo. Phytopathology 70:958-961

Poëssel JL, Corre M, Kervella J et al. (2002) Increase in phenolic content in the resistant peach cultivar "Rubira®" infested by the green peach aphid, Myzus persicae - In: El Hadrami, I (ed.), XXI Int Conf on Polyphenols - Groupe Polyphenols Publisher Vol 1:131-132

Rajapakse S, Belthoff LE, He G, Estager AE, Scorza R, Verde I, Ballard RE, Baird WV, Callahan A, Monet R, Abbott AG (1995) Genetic linkage mapping in peach using morphological, RFLP and RAPD markers. Theor Appl Genet 90:503-510

Rossi M, Goggin FL, Milligan SB, Kaloshian I, Ullman DE, Williamson VW (1998) The nematode resistance gene $\mathrm{Mi}$ of tomato confers resistance against the potato aphid. Proceedings of the National Academy of Sciences of the United States of America 95:9750-9754.

Rubio M, Pascal T, Bachellez A, Lambert P (2010) Quantitative trait loci analysis of Plum pox virus resistance in Prunus davidiana P1908: new insights on the organization of genomic resistance regions. Tree Genet Genomes (2010) 6:291-304

Sauge MH, Kervella J, Rahbé Y (1998a) Probing behaviour of the green peach aphid Myzus persicae on resistant Prunus genotypes. Entomologia Experimentalis et Applicata 89:223-232 
Sauge MH, Kervella J, Pascal T (1998b) Settling behaviour and reproductive potential of the green peach aphid Myzus persicae on peach varieties and a related wild Prunus. Entomologia Experimentalis et Applicata 89:233-242

Sauge MH, Lacroze JP, Poëssel JL, Pascal T, Kervella J (2002) Induced resistance by Myzus persicae in the peach cultivar "Rubira®". Entomologia Experimentalis et Applicata 102:29-37

Sauge MH, Pascal T, Lacroze JP, Pfeiffer F and Kervella J (2004) Mapping of a genetic factor of partial resistance to Myzus persicae in the wild peach Prunus davidiana, that impedes phloem sap ingestion by the aphid. - In : Simon J.C., Dedryver C.A., Rispe C. et al. (eds), Aphids in a New Millennium, INRA Editions, Versailles, pp 499-505

Sauge MH, Mus F, Lacroze JP, Pascal T, Kervella J, Poëssel JL (2006) Genotypic variation in induced resistance and induced susceptibility in the peach-Myzus persicae aphid system. Oikos 113:305-313

Sicard O, Marandel G, Soriano JM, Lalli DA, Lambert P, Salava J, Badenes M, Abbott A, Decroocq V (2007) Flanking the major Plum pox virus resistance locus in apricot with co-dominant markers (SSRs) derived from candidate resistance genes. Tree Genet Genomes 4:359-365

Sosinski B, Gannavarapu M, Hager LD, Beck LE, King GJ, Ryder CD, Rajapakse S, Baird WV, Ballard RE, Abbott AG (2000) Characterization of microsatellite markers in peach (Prunus persica L. Batsch). Theor Appl Genet 101:421-42

Tagu D, Klingler JP, Moya A, Simon JC (2008) Early progress in aphid genomics and consequences for plantaphid interactions studies. MPI Vol. 21, 6:701-708

Testolin R, Marrazzo T, Cipriani G, Quarta R, Verde I, Dettori M, Pancaldi M, Sansavini S (2000) Microsatellite DNA in peach (Prunus persica L. Batsch) and its use in fingerprinting and testing the genetic origin of cultivars. Genome 43:512-520

Testolin R, Messina R, Lain O, Marrazzo MT, Huang WG, Cipriani G (2004) Microsatellites isolated in almond from an AC-repeat enriched library. Mol Ecol Notes 4:459-461

Van Ooijen JW (2004) MapQTL ${ }^{\circledR}$ 5, Software for the mapping of quantitative trait loci in experimental populations. Kyazma BV, Wageningen, Netherlands.

Verde I, Lauria M, Dettori MT, Vendramin E, Balconi C, Micali S, Wang Y, Marrazzo MT, Cipriani G, Hartings H, Testolin R, Abbott AG, Motto M, Quarta R (2005) Microsatellite and AFLP markers in the Prunus persica $\left[\mathrm{L}\right.$. (Batsch) $\times P$. ferganensis $\mathrm{BC}_{1}$ linkage map: saturation and coverage improvement. Theor Appl Genet 111:1013-1021

Voorrips RE (2002) MapChart: Software for the graphical presentation of linkage maps and QTLs. The Journal of Heredity 93 (1):77-78

Wroblewski T, Piskurewicz U, Tomczak A, Ochoa O, Michelmore RW (2007) Silencing of the major family of NBS-LRR-encoding genes in lettuce results in the loss of multiple resistance specificities. The Plant Journal 51:803-818

Yamamoto T, Mochida K, Imai T, Shi YZ, Ogiwara, I, Hayashi T (2002a) Microsatellite markers in peach [Prunus persica (L.) Batsch] derived from an enriched genomic and cDNA libraries. Mol Ecol Notes 2:298301

Yamamoto T, Hayashi T (2002b) New root-knot nematode resistance genes and their STS markers in peach. Sci Hortic 96:81-90

Yamamoto T, Yamaguchi M, Hayashi T (2005) An Integrated Genetic Linkage Map of Peach by SSR, STS, AFLP and RAPD. J Japan Soc Hort Sci 74:204-213

Zeng ZB (1994) Precision mapping of quantitative trait loci. Genetics 136:1457-1468 
Table 1 Origin and number of Prunus simple sequence repeat markers tested for amplification and polymorphism and used in the development of the 'Pamirskij5' $\mathrm{x}$ 'Rubira' $\mathrm{F}_{2}$ genetic linkage map

\begin{tabular}{|c|c|c|c|c|c|c|c|}
\hline SSR name & Prunus species & Origin & Tested & Amplified & Polymorphic & Mapped & Reference \\
\hline AMPA & P. armeniaca & Genomic & 16 & 15 & 8 & 4 & Hagen et al. (2004) \\
\hline AMPA & P. armeniaca & cDNA & 10 & 9 & 4 & 2 & Hagen et al. (2004) \\
\hline BPPCT & P. persica & Genomic & 39 & 39 & 22 & 19 & Dirlewanger et al. (2002) \\
\hline $\mathrm{Cd}$ & P. persica & Genomic & 3 & 3 & 2 & 1 & Sicard et al. (2008) \\
\hline CPDCT & P. dulcis & Genomic & 33 & 30 & 7 & 4 & Mnejja et al. (2005) \\
\hline СРPCT & P. persica & Genomic & 27 & 27 & 11 & 11 & Aranzana et al. (2002) \\
\hline CPSCT & P. salicina & Genomic & 26 & 24 & 7 & 4 & Mnejja et al. (2004) \\
\hline EMPA & P. avium & Genomic & 4 & 4 & 1 & 1 & Clarke and Tobutt (2003) \\
\hline EPDCU & P. dulcis & cDNA & 3 & 3 & 3 & 1 & GDR \\
\hline EPPB & P. persica & cDNA & 20 & 20 & 3 & 2 & GDR \\
\hline EPPCU & P. persica & cDNA & 74 & 71 & 27 & 7 & GDR \\
\hline $\mathrm{G}$ & P. persica & Genomic & 4 & 4 & 3 & 1 & Marandel et al. (2009) \\
\hline M & P. persica & cDNA & 6 & 4 & 3 & 3 & Yamamoto et al. (2002) \\
\hline MA & P. persica & Genomic & 21 & 19 & 13 & 10 & Yamamoto et al. (2002) \\
\hline Pac & P. armeniaca & cDNA & 11 & 11 & 2 & 2 & Decroocq et al. (2003) \\
\hline PceGA & P. cerasus & Genomic & 1 & 1 & 1 & 1 & Downey and Iezzoni (2000) \\
\hline pchcms & P. persica & cDNA & 5 & 5 & 3 & 1 & Sosinski et al. (2000) \\
\hline pchgms & P. persica & Genomic & 10 & 10 & 6 & 5 & $\begin{array}{l}\text { Sosinski et al. (2000) } \\
\text { Verde et al. (2005) }\end{array}$ \\
\hline PdavW & P. davidiana & Genomic & 1 & 1 & 0 & 0 & Lambert et al. (2004) \\
\hline pms & P. avium & Genomic & 5 & 5 & 1 & 1 & Cantini et al. (2001) \\
\hline PS & P. avium & Genomic & 5 & 4 & 1 & 1 & $\begin{array}{l}\text { Sosinski et al. (2000) } \\
\text { Joobeur et al. (2000) }\end{array}$ \\
\hline ssrPaCITA & P. armeniaca & Genomic & 21 & 17 & 5 & 2 & Lopes et al. (2002) \\
\hline UDA & P. dulcis & Genomic & 4 & 4 & 2 & 1 & Testolin et al. (2004) \\
\hline UDAp & P. armeniaca & Genomic & 63 & 59 & 26 & 14 & Messina et al. (2004) \\
\hline \multirow[t]{2}{*}{ UDP } & $P$. persica & Genomic & 25 & 25 & 19 & 17 & $\begin{array}{l}\text { Cipriani et al. (1999) } \\
\text { Testolin et al. (2000) }\end{array}$ \\
\hline & & Total & 437 & 414 & 180 & 116 & \\
\hline
\end{tabular}

GDR : Genome Database for Rosacea (http://www.rosaceae.org/) 
Table 2 Summary of the QTLS detected by Kruskal-Wallis test (KW) and Composite Interval Mapping (CIM) for Trial 1. LOD scores below the significant threshold are in italics.

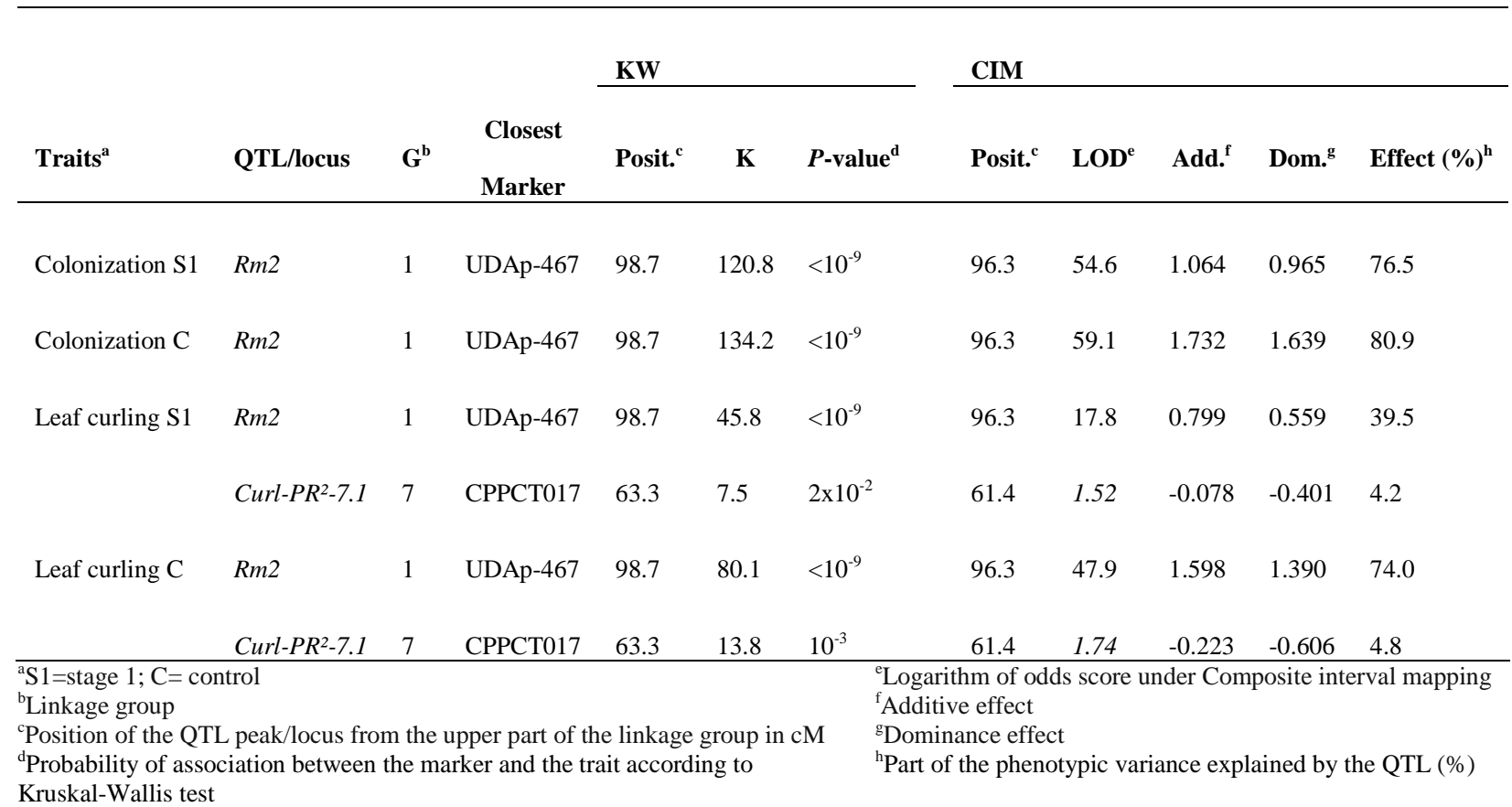


G1

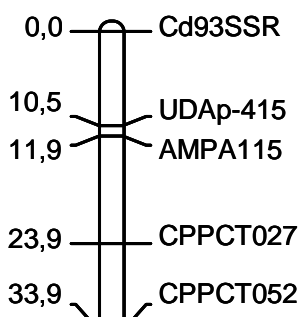

36,0 UDAp-419

38,3 UDP-005

40,2 PacA18

41,0 \UDAp-426

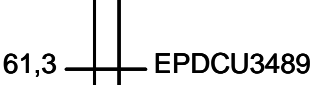

65,7 1 G22SSR

75,3 pchgms28

79,5 AMPA109

80,6 LEMPA011

81,6 ВPРCT019C

90,2 UDP-022

90,7 - pchgms29

96,6 $\rightarrow$ Rm2

$98,7-{ }_{\text {UDAp-467 }}$

G5

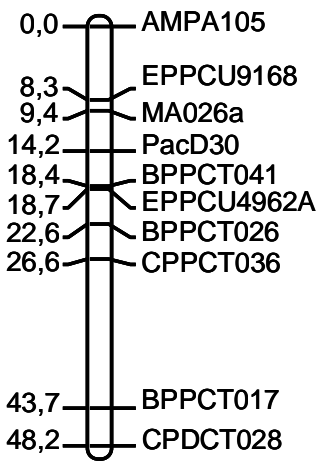

G2

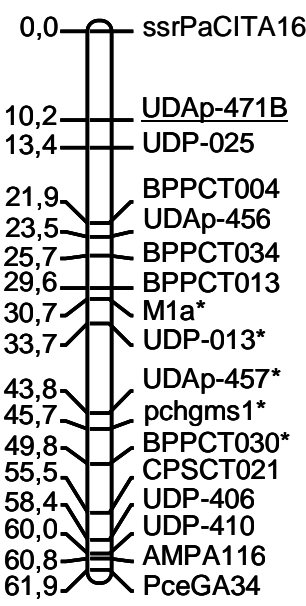

G6

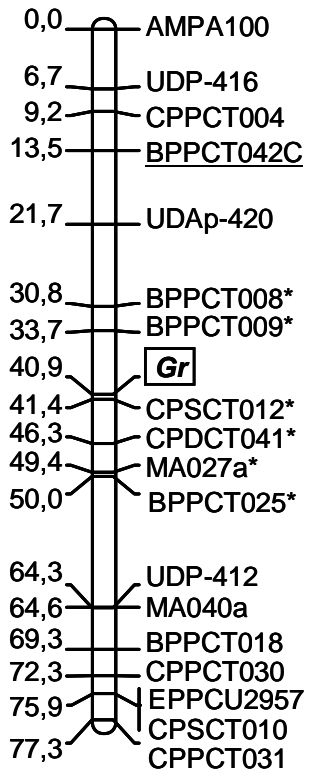

G3

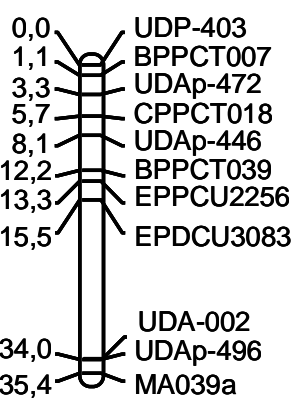

G7

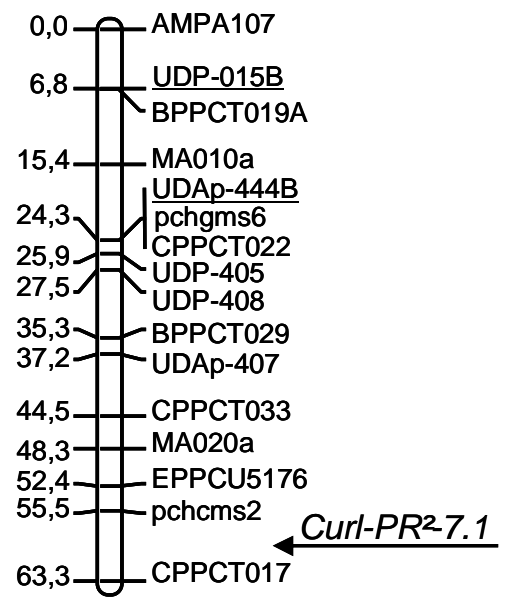

G4

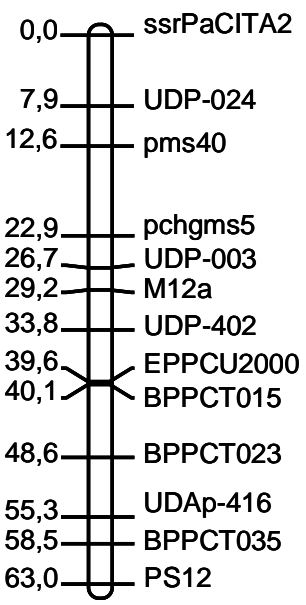

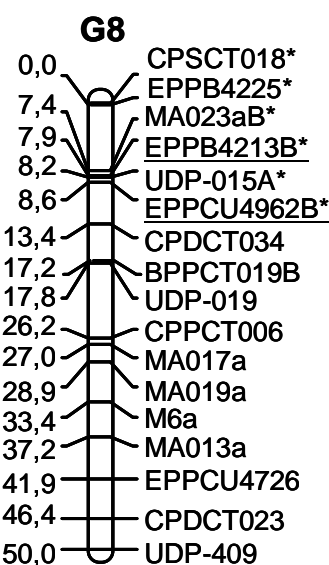

Fig. 1 Linkage map derived from the "Pamirskij 5" $\times$ "Rubira ${ }^{\circledR,} F_{2}$ population. The different loci mapped with a SSR primer pair are shown with a capital letter (A, B, C) following the locus name. Loci not mapped in other published maps are underlined. Loci followed by an asterisk after the locus name have distorted segregations $(\mathrm{P}<0.1)$. Framed loci in italics are the morphological markers. The putative QTL in G7 is figured with an arrow on the right of the linkage group. 
G6a

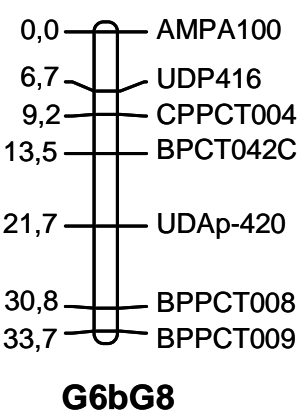

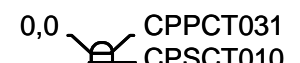

1,4 CPSCT010

5,0 $\mathrm{CPPCT030}$

8,0

12,7 MA040A

13,0 \UDP-412

$27,3 \sqrt{\text { BPPCT025 }}$

$27,9>$ MA027aA

30,9 CPDCT041

42,3

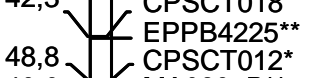

49,6 MA023aB ${ }^{\star *}$

49,9 Gr $^{*}$

50,2 - ЕPPB4213B**

$50,5=1$ UDP-015A**

50,9 EPPCU4962

55,6 \ CPDCT034

$59,4]=[$ BPPCT019B

$60,0]$ [ UDP-019

68,4 CPPCT006

69,2 MA017a

71,1 MA019a

$75,6 / \triangle \mathrm{M}$

79,4 MA013a

84,1 EPPCU4726

88,6 \& CPDCT023

92,2 UDP-409
G6

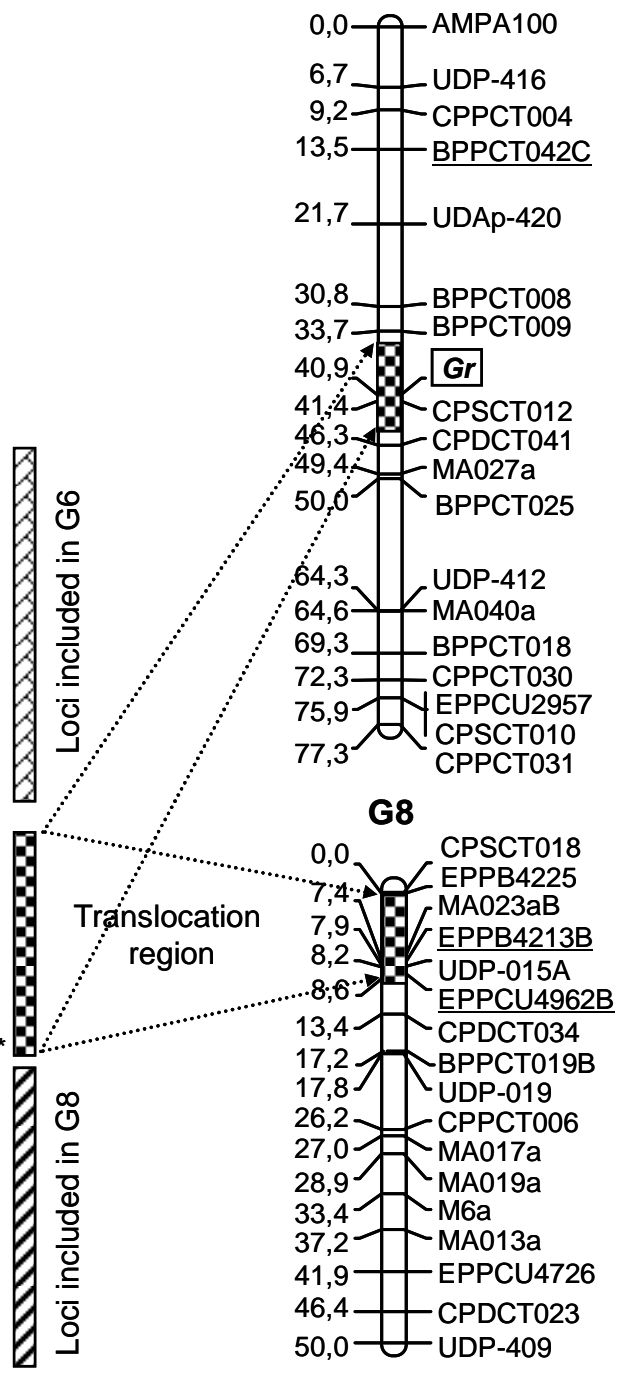

Fig. 2 Linkage groups 6 and 8 of the $P^{2}$ genetic map showing the position of the translocation region. On the left of the figure: linkage group obtained with a LOD $>19.0$; it is composed of all the markers of G6 and G8 grouped by pseudo-linkage. Loci followed by an asterisk in the translocation region belong to G6; those followed by two asterisks belong to G8. Bars on the right of the pseudo linkage group indicate the linkage group to which the loci belong to. 
A)

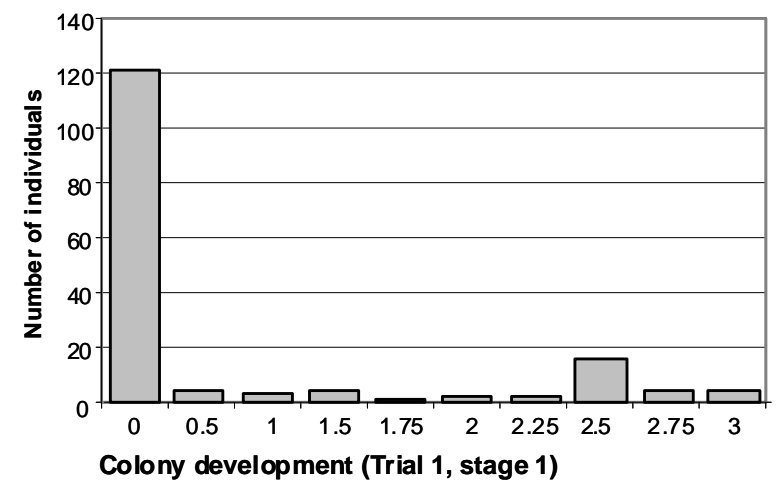

C)

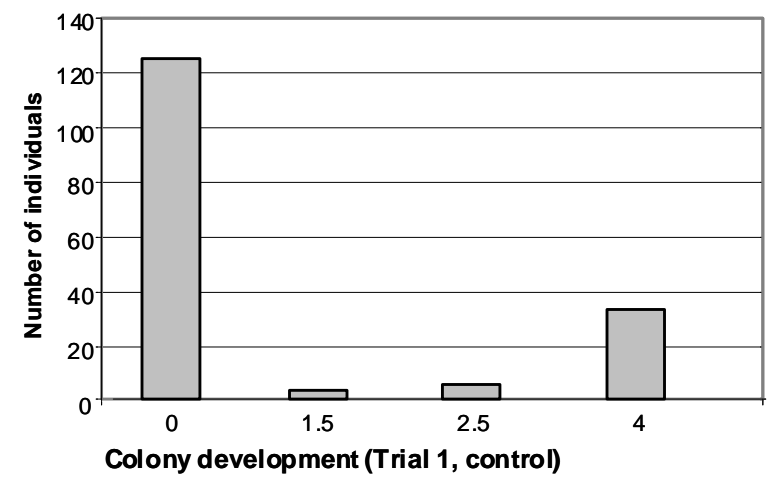

B)

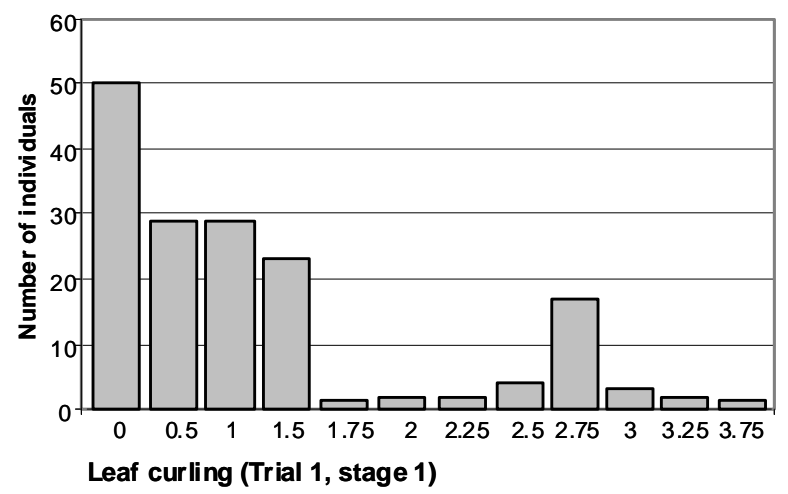

D)

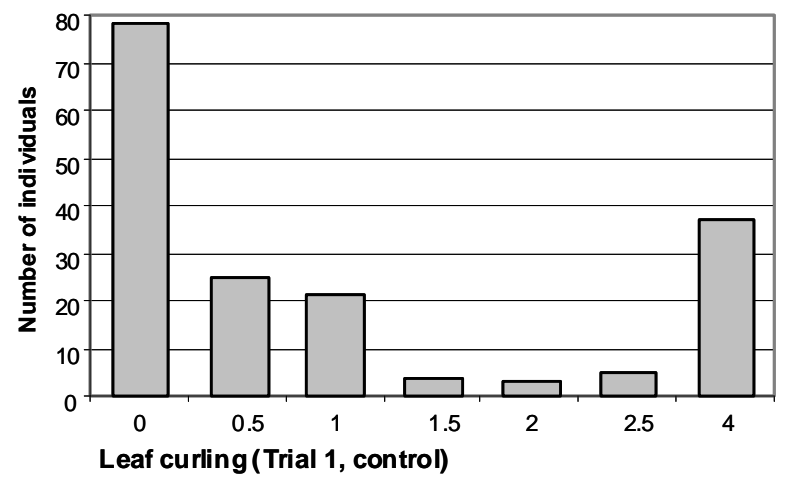

Fig. 3 GPA colonization and leaf curling score distributions for Trial 1 dataset at stage 1 (A, B) and control (C, D). On the ordinate: number of seedlings; on the abscissa: degree of colony development or leaf curling according to the ordinal scale used. 